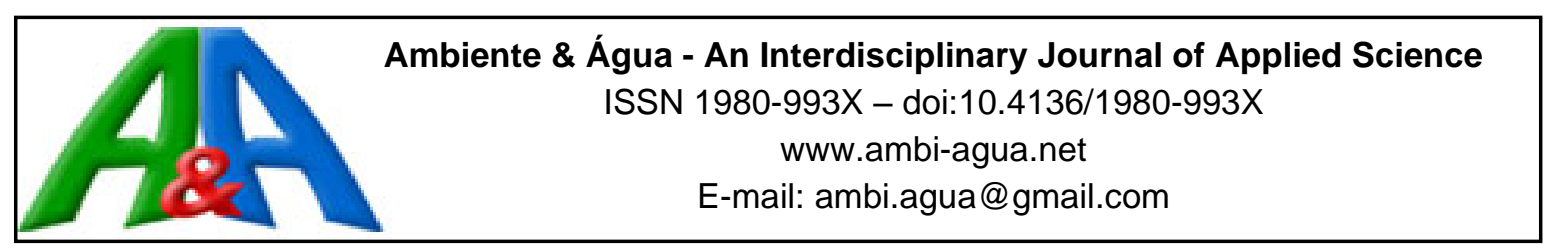

\title{
Quality index of permanent preservation areas of urban water resources: PPAWater
}

\author{
ARTICLES doi:10.4136/ambi-agua.2589
}

Received: 02 Jun. 2020; Accepted: 28 Dec. 2020

\section{Francisca Dalila Menezes Vasconcelos ${ }^{1 *}$; Francisco Suetônio Bastos Mota ${ }^{1}$; Maria Cléa Brito de Figueirêdo 2}

\begin{abstract}
${ }^{1}$ Departamento de Engenharia Hidráulica e Ambiental. Universidade Federal do Ceará (UFC), Campus do Pici, Bloco 713, CEP: 60455.760, Fortaleza, CE, Brazil. E-mail: suetonio@ufc.br ${ }^{2}$ Embrapa Agroindústria Tropical (EMBRAPA), Rua Doutora Sara Mesquita, n 2270, CEP: 60511-110, Fortaleza, CE, Brazil. E-mail: mariacleabrito@gmail.com *Corresponding author. E-mail: menezes.dalila@gmail.com
\end{abstract}

\begin{abstract}
Urban expansion is widely acknowledged to have a substantial impact on water bodies. The objective of this work is to propose and apply a composite index to evaluate the quality of Permanent Preservation Areas (PPAs), which protect urban rivers. The PPAWater index aggregates information from six indicators, namely, sanitary sewage, precarious settlement, urban drainage, level of occupation, conservation units, and preservation area, established by the municipal master plan. When applied to sub-basins in the city of Fortaleza, Ceará, the fifth most-populated city in Brazil, the index shows that the localities lacking sufficient sanitation infrastructure and with fewer hectares of protected areas register as the most vulnerable PPAs. The PPAWater index is an important tool to guide urban environmental planning, formulation, and management of public policies for the protection of urban water resources. It can be used by municipal managers to evaluate environmentally sensitive areas.
\end{abstract}

Keywords: urban development, urban environmental indicators, urban water.

\section{Índice de qualidade das Áreas de Preservação Permanente dos recursos hídricos urbanos: APPHidro}

\section{RESUMO}

Os impactos da expansão urbana nos recursos hídricos é uma relação amplamente aceita. Propor e aplicar um índice composto para avaliar a qualidade das Áreas de Preservação Permanente (APP), que protegem os rios urbanos, é o objetivo deste trabalho. O APPHidro agrega informações de seis indicadores: esgotamento sanitário, assentamento precário, drenagem urbana, nível de ocupação, Unidades de Conservação e Zona de Preservação instituídas pelo plano diretor municipal. Aplicado nas sub-bacias inseridas na cidade de Fortaleza-Ceará, a quinta mais populosa do Brasil. O índice mostra que as localidades menos assistidas por infraestrutura de saneamento, e com menos hectares de áreas protegidas, registram APP mais vulneráveis. O índice APPHidro apresenta-se como uma ferramenta importante na orientação do planejamento urbano ambiental, formulação e gestão de políticas públicas no âmbito da proteção dos mananciais urbanos. Além de subsidiar gestores municipais sobre as zonas ambientalmente sensíveis que necessitam de recuperação. 
Palavras-chave: águas urbanas, desenvolvimento urbano, indicadores urbanos ambientais.

\section{INTRODUCTION}

Studies in several countries have confirmed that increased urbanization affects water quality in cities. Tu (2011) highlighted urban expansion as the main cause of water-resource pollution. Huang et al. (2015) stated that urban sprawl more severely impacts water quality in urbanized hydrographic basins. The definition of water resources in the present work refers to the natural urban rivers, channeled rivers, lagoons, lakes and streams of the city. The primary function of permanent preservation areas (PPAs) of urban water resources is the preservation of water resources and the quality of water available to the urban population. In Brazil, the Forest Code (Federal Law n. 12,651/12) delimits and regulates such areas. Some municipalities delimit their water source areas through municipal zoning established in the Municipal Master Plan (MMP).

In other countries, federal or local legislation delimit and regulate these areas. Some laws adopt delimitation criteria such as a guarantee of environmental services (Switzerland), degree of occupation (Canada), rigorous environmental licensing process (United Kingdom), and a guarantee of space for free flowing water and quality of water ecosystems (France) (Pedroso Jr. et al., 2015; Gass et al., 2016). This delimitation of PPAs, both by the federal and local government, leads to fragmented competencies and legal inconsistencies, hindering the protection of water resources and their area of influence and increasing the vulnerability of these areas to urban expansion. Thus, PPAs of urban water resources frequently present conflicts in regard to their delimitations.

Therefore, it is necessary to study, monitor, and evaluate the quality of PPAs behaving as important soil-water transition zones, which exhibit significant complexities within the urban context. These transition zones are important for the prevention of disasters, help preserve water resources, and guarantee the local hydrological regime. Environmental indexes and indicators are important tools for understanding the level of environmental degradation in urban water body PPAs (Klopp and Petretta, 2017). These tools help in the evaluation of spatiotemporal conditions and trends, allow for the analysis of progress toward established goals of conservation and environmental preservation, support decision making, raise awareness, and encourage political and behavioral changes (Moreno Pires et al., 2014).

In Brazil, the main sets of indicators and indexes relate to geomorphological parameters, urban infrastructure, and demographic data (Freitas et al., 2013; Barros et al., 2015; Ribeiro and Mendes, 2015; Dellamora et al., 2013). Indexes found in international literature pertain to water quality and land use parameters to assess the degradation of water sources owing to urban expansion (Zhao et al., 2015; Uriarte et al., 2011; Singh et al., 2016; Carstens and Amer, 2019), with no emphasis on PPAs.

This work proposes and applies a new index, the PPAWater index, to assess the level of degradation of urban water resources. The unique feature of this index is that it does not employ water quality monitoring data, which are usually unavailable in developing countries. Furthermore, it employs an innovative territorial limit (sub-basins at the territorial limit of the municipality) and is easy to apply as it is based on information available in existing databases. The main objective of this work is to provide a composite index to evaluate the quality of urban water resources PPAs. Evaluation results using this index can help decision makers in the adequate management of PPAs such that environmental services in these areas, essential in the urban context, may be improved. The article includes three further sections: methodological construction of the index; application of the index through a case study of the city of Fortaleza, and final considerations on the index proposal and application experience. 


\section{MATERIALS AND METHODS}

The methodological steps for the construction of the composite index are based on the Handbook on Constructing Composite Indicators by the OECD (Organization for Economic Co-operation and Development) published in 2008 (OECD, 2008).

\subsection{Bibliographic review as support for the selection of indicators}

In order to analyze the existing indicators and determine ones that could compose the PPAWater composite index, the Scielo and Science Direct databases were searched with the following keywords and combinations in Portuguese and English: "areas of preservation of urban watercourses"; "environmental indicators"; "indexes and indicators of urban water bodies"; "environmental management indicators"; "urban indicators"; and "indicators of urban sustainability".

Nine articles were selected that presented indicators more related to the subject under study (Table 1). The selection criteria for the other articles were: 1) models developed for urbanized watersheds; 2) models focused on the relationship of water resources and their protection areas; and 3) models applied to urban centers that underwent an intense urbanization process in a short period of time.

The international models (Table 1) can be applied in Brazil, considering in situ water quality analyses. However, most Brazilian urban centers do not provide data on river water quality, which makes the application of these models difficult. Thus, two scenarios for the construction of indicators for urban water resources PPAs were observed, one for developed countries and another for developing countries. In developed countries and localities such as China (Zhao et al., 2015; Huang et al., 2015; Xie et al., 2018), United States (Cartens and Amer, 2019), and Puerto Rico (Uriarte et al., 2011), water quality, land use, and occupation parameters are used to assess the impact of urban expansion on water resources.

These countries usually display fully functioning urban and sanitation infrastructure, especially in environmentally relevant areas. In these countries, the availability of official information on the monitoring of water quality and land use enables the establishment of a direct relationship between water quality and the state of conservation of water resources PPAs.

On the other hand, developing countries use proxy indicators, mainly due to the absence of water quality data. Some countries like India (Sing et al., 2016) and Argentina (Calderon et $a l ., 2014$ ) have even studied the direct relationship between water quality and urbanization, but these parameters were obtained on the field, and were not a part of a systematic monitoring work. However, it is not of interest to use water quality indicators for the proposed index, because periodic collection and analysis of all parameters would be quite expensive. Thus, the index avoids the in situ collection of data and promotes the use of available official secondary data.

The models currently available for analysis of the situation of urban water resource PPAs do not use management and environmental legislation indicators, which are essential for urban environmental areas (usually managed by local management). Moreover, some often-used indicators, such as proximity to native vegetation, proximity to urban areas, proximity to the road network, risk of erosion (Freitas et al., 2013), slope, and soil type (Barros et al., 2015) are not applicable in urban environments that undergo drastic transformations, with little or no original vegetation fragments. With this context, the PPAWater composite index will be composed of six proxy indicators; these are detailed in subsection 3.1. 
Table 1. Indicators identified from the bibliographic survey for structuring the PPAWater model in 2020.

\begin{tabular}{|c|c|c|c|}
\hline Indexes/ Indicators & Locality/Author/Year & Measurement parameters & Contribution \\
\hline \multirow{5}{*}{$\begin{array}{l}\text { Land use indicators and } \\
\text { Water quality parameters }\end{array}$} & $\begin{array}{l}\text { China. } \\
\text { Zhao et al. (2015). }\end{array}$ & $\begin{array}{l}\text { LUP: level of urbanization, environmental management, expansion } \\
\text { of the industrial zone, land-use composition. } \\
\text { WQP: Biochemical oxygen demand, nitrate, and phosphorus. }\end{array}$ & Correlates urban expansion to water quality. \\
\hline & $\begin{array}{l}\text { Peru. } \\
\text { Carpio and Fath (2011). }\end{array}$ & $\begin{array}{l}\text { LUP: pasture, agriculture, volcanic material, water, empty land. } \\
\text { WQP: fecal coliforms. Absolute numbers of cases of } \\
\text { gastrointestinal diseases. }\end{array}$ & $\begin{array}{l}\text { Studies the direct relationship of urban } \\
\text { expansion with changes in river flow, water } \\
\text { quality, and waterborne diseases. }\end{array}$ \\
\hline & $\begin{array}{l}\text { Puerto Rico. } \\
\text { Uriarte et al. (2011). }\end{array}$ & $\begin{array}{l}\text { LUP: agriculture, forest, pasture, water, urban area, swamp. } \\
\text { WQP: turbidity, dissolved oxygen, total phosphorus, nitrogen, fecal } \\
\text { coliforms, and streptococci. }\end{array}$ & $\begin{array}{l}\text { Links urban expansion and pasture to water } \\
\text { quality. }\end{array}$ \\
\hline & $\begin{array}{l}\text { India. } \\
\text { Singh et al. (2016). }\end{array}$ & $\begin{array}{l}\text { LUP: agriculture, built area, and vegetation. } \\
\text { Applying the Water Quality Index (WQI). }\end{array}$ & $\begin{array}{l}\text { States that urbanization is the cause of water } \\
\text { pollution. }\end{array}$ \\
\hline & $\begin{array}{l}\text { United States. } \\
\text { Carstens and Amer (2019). }\end{array}$ & $\begin{array}{l}\text { LUP: agriculture, forest, pasture, water, urban area. } \\
\text { WQP: dissolved oxygen, total phosphorus, nitrogen, and fecal } \\
\text { coliform. }\end{array}$ & $\begin{array}{l}\text { The results state that urbanization has a } \\
\text { negative impact on water quality. }\end{array}$ \\
\hline $\begin{array}{l}\text { Environmental indicators } \\
\text { of PPA }\end{array}$ & $\begin{array}{l}\text { Brazil. } \\
\text { Freitas et al. (2013). }\end{array}$ & $\begin{array}{l}\text { Parameters: land use, proximity to vegetation and urban areas, } \\
\text { proximity to the road network, risk of erosion, capacity to sustain } \\
\text { the native forest, order of drainage channels, and PPA category. }\end{array}$ & $\begin{array}{l}\text { The study found that } 44 \% \text { of local PPAs were } \\
\text { in compliance. }\end{array}$ \\
\hline $\begin{array}{l}\text { Urban Environmental } \\
\text { Quality Index }\end{array}$ & $\begin{array}{l}\text { Brazil. } \\
\text { Ribeiro and Mendes (2015). }\end{array}$ & $\begin{array}{l}\text { LUP: vegetation coverage, basic infrastructure, and demographic } \\
\text { data. }\end{array}$ & $\begin{array}{l}\text { Methodological contributions applying remote } \\
\text { sensing and multivariate analysis. }\end{array}$ \\
\hline Sustainability Indicators & $\begin{array}{l}\text { Brazil. } \\
\text { Dellamora et al. (2013). }\end{array}$ & LUP: land use, green areas, water resources, and PPA land. & $\begin{array}{l}\text { Methodological contributions applying remote } \\
\text { sensing and Geographic Information System. }\end{array}$ \\
\hline $\begin{array}{l}\text { Environmental } \\
\text { Vulnerability Index }\end{array}$ & $\begin{array}{l}\text { Brazil. } \\
\text { Barros et al. (2015). }\end{array}$ & $\begin{array}{l}\text { LUP: declivity, land and area of riparian forest PPA, i.e., the } 30 \mathrm{~m} \\
\text { required by law. }\end{array}$ & $\begin{array}{l}\text { Relates PPA with social vulnerability, } \\
\text { infrastructure, and urban flood risk. }\end{array}$ \\
\hline
\end{tabular}

Legend: Index of qualities of Urban Water Resource Preservation Areas; LUP - Land Use Parameters; WQP - Water Quality Parameters. 


\subsection{Hierarchization of indicators: Delphi method}

The objective of hierarchization of the indicators, which are part of the composite index, is to assess which indicators are most influential and relevant in the process, as well as those that are the least relevant. The results of this ranking will support the weighting of the indicators to be carried out in the normalization stage. The hierarchization of indicators that comprise the PPAWater index was carried out using the Delphi method, which has been used and improved by over 2,600 academic articles. This method allows for the collection of insights from a group of experts, whose anonymity is maintained to exclude biases that could arise from the group's interactions (Flostrand et al., 2020). The process followed the steps proposed by Marques and Freitas (2018): 1) Stating the problem and structuring the research; 2) Preparation of the questionnaire; 3) Selection of the expert group; 4) Surveying using questionnaires; 5) Reflection and response of experts; 6) Analysis of the answers by the researcher; 7) Compilation of responses and elaboration of the final report.

According to Godet and Durance (2011), the number of experts in the interviewed group should not be less than 25 . Thus, 25 professionals from agencies and institutions that directly influence the urban environmental planning process of the city of Fortaleza were interviewed. These 25 professionals carried out a peer review through the direct influence matrix. Then, a median of the weights assigned by the experts was extracted. This median was used in the MICMAC® software (Matrix of Cross Impacts and Multiplications Applicable to a Classification) to construct the influence matrix in order to obtain a ranking of importance/influence of indicators.

\subsection{Weight assignment, standardization, and aggregation of indicators}

The Analytic Hierarchy Process (AHP) was applied using the obtained ranking of the six indicators. A decomposition and synthesis of the relationships between the criteria were performed until a prioritization of their indicators was determined (Saaty, 1991). Once the weights of the indicators were assigned, the standardization stage was carried out. According to Reisi et al. (2014), when data present different units of measurement, they become immeasurable. Hence, it is necessary to apply the same unit of measurement to make them compatible; this method is called normalization. The unit adopted for normalization was the percentage of PPA area in hectares, since the analysis of the indicators was carried out via map algebra, using spatial information of the studied territory. In each indicator equation, the sum of the areas in hectares was used, which was later multiplied by 100 to obtain the percentage of each component in the total PPA of the municipality under study. The adopted method for indicator aggregation was the comparable interval scale, where aggregation was carried out based on the arithmetic mean, generating an index with strong data representativity (Feil and Schreiber, 2017).

\subsection{Map algebra in delimiting areas and applying the index}

Once the study area was selected, map algebra was applied to: 1) define the area of water resource and their PPAs; 2) calculate the areas of each indicator comprising the PPAWater index; and, 3) prepare the map with the index scale by sub-river basins. The first step in applying the index was the delimitation of the PPAs of urban water bodies based on existing watercourses and regulations specified by the Brazilian Forestry Code. The cartographic database of the city was used to support the delimitation of PPAs and aid in the preparation of maps. The contour lines were consulted to verify the limits of the water courses for design refinement of the cartographic maps. Satellite images obtained by Bing Maps and Google Earth were also used, with updated images from 2019.

Based on the shape of the water resources, the buffer tool of the QGIS software, Version 7.6.1 (Grass), was used to delimit the PPAs, following the limits specified in the Brazilian Forest Code. The delimitation presented different profiles of protection areas, generating the 
following PPA typologies of the watercourses identified in the river basins: PPA-1: Lakes and ponds with a $30 \mathrm{~m}$ minimum width protection strip; PPA-2: Minimum $30 \mathrm{~m}$ protection strip for watercourses less than $10 \mathrm{~m}$ wide; PPA-3: Minimum $50 \mathrm{~m}$ protection strip for watercourses 10 to $50 \mathrm{~m}$ wide; PPA-4: Minimum $100 \mathrm{~m}$ protection strip for watercourses 50 to $200 \mathrm{~m}$ wide; PPA-5: Minimum $200 \mathrm{~m}$ protection strip for watercourses 200 to $600 \mathrm{~m}$ wide; PPA-6: Minimum $500 \mathrm{~m}$ protection strip for watercourses over $600 \mathrm{~m}$ wide; and PPA-7: Channeled stretches with a $30 \mathrm{~m}$ minimum protection strip.

Maps and area calculations were also obtained using the QGIS software. Remote sensing, geographic information systems, and map algebra are widely used in urban environmental planning (Hegazy and Kaloop, 2015; Coutts et al., 2016; Liu et al., 2017; Tu et al., 2018; Gao et al., 2019; Frick and Tervoonren, 2019). The archives used for the elaboration of the maps and calculation of the areas can be found on the "Fortaleza em mapas" platform (Fortaleza, 2020) of the city of Fortaleza, from 2018 to 2020.

\subsection{Strategy for defining the scale and territorial limit and characterization of the area of study}

Two types of spatial delimitation were integrated in order to delimit the study area, that is, the river basin and the municipal boundaries. The division of the river basin is recommended for the study of water resource management (Aquino and Mota, 2019). However, urban managers and planners, who work with municipal boundaries and are responsible for the elaboration of laws and guidelines for land planning and use, do not usually adopt this division, especially for urban water resources PPAs. The joint application of spatial delimitations (watershed and municipal boundaries) facilitates the needs of urban planners and environmental managers who work with urban water resource management in municipalities. This innovative approach is used here for the first time in the study of PPAs of rivers in urban areas.

This work applies the PPAWater index to the river sub-basins of the municipal territory of the city of Fortaleza (Ceará-Brazil), which was selected owing to its intense urban growth, decrease in environmental areas, and visible socioeconomic inequality of the population In 2018, the population of Fortaleza was estimated to be 2.643 million, with a forecasted population of 2.669 million by 2019 (IBGE, 2019). The municipality has four hydrographic basins in its territory, namely, Cocó River, Maranguapinho River, Pacoti River, and Vertente Marítima; the first two correspond to $82 \%$ of the municipal area (Ceará, 2018). According to Koppen's classification, the climate is rainy tropical, with a strong rainfall irregularity throughout the year, and a rainy season from May to April (Marino et al., 2012). Public water resource policies are relevant to the region, considering the context of water scarcity.

The water supply of a city is sourced from hydrographic basins outside the city (approximately $300 \mathrm{~km}$ away). This integrated hydrographic basin system guarantees water supply for the city, compensating for the water scarcity in the hydrographic basins of the city. The treatment of water distributed to the city is carried out through a concession by a concessionaire, which is also responsible for the sewage system. The urban drainage system is managed by the city government through the Municipal Secretariat of Urban Infrastructure.

\section{RESULTS AND DISCUSSION}

\subsection{Justification of indicators selected to compose the PPAWater index}

The literature review contributed to the selection of six proxy indicators that are categorized in two dimensions as follows:

- Urban indicators (UI): UI-1: sanitary sewage system, UI-2: urban drainage system, and UI-3: precarious settlements. 
- Environmental and management indicators (EI): EI-1: vegetation coverage, EI-2: conservation units (CUs), and EI-3: municipal environmental macro-zoning.

The selection of indicators for the urban dimension accounts for the infrastructure that allows for better functioning of the ecosystem services developed by water resources PPAs. This urban infrastructure (sewage services, drainage system, supply, and collection of solid waste) facilitates more efficient urban water dynamics, avoiding the release of sewage into water bodies and improper disposal of solid waste in water bodies. The indicator "PPA with vegetation cover" behaves as a proxy indicator for permeable areas. This indicator also helps in the identification of occupied PPA fractions, i.e., impermeable areas occupied by buildings. According to Leite et al. (2019), the native vegetation in the vicinity of watercourses plays an important role in maintaining the quantity and quality of water by acting as a sediment filter. Riparian forests with poplar trees reduce the nitrogen and phosphorus content in soil and act as a form of green infrastructure to eliminate nonpoint source pollution for improved ecological watershed management (Bahn and $\mathrm{Na}, 2020$ ). According to Zhao et al. (2015), the environmental management system is the most important contributor to the reduction of pollution in urban districts. They stated that efficient management of water resources improves water quality, even in areas with intense urban expansion.

The main differences between the PPAWater index and existing ones are: its applicability in densely urbanized areas including severely transformed rivers (channeled stretches, which alter the hydraulic regime of the river, silted and eutrophic lagoons, among other changes) by urbanization; the insertion of a territorial limit for sub-basins in the municipality under study; the accessibility of secondary data, without the need for in situ collection; ease of understanding of the colorimetric scale, which can be disseminated to the general public; and the integration of both management and infrastructure indicators in the same index.

Certain aspects of correlation and compensation between indicators are listed, reiterating their importance in the composition of the index. The UI-3 indicator, which pertains to illegal settlements of a location, is different from conventional occupation, which are subject to tribute and generally connected to sanitary sewage systems, water supply, domestic waste collection, and other urban services. For management indicators, the CUs follow the guidelines set by the International Union for the Conservation of Nature (IUCN), which aims to safeguard important natural habitats that are under threat. As for municipal macro-zoning defined by the MMP, the delimitation of the water source preservation areas is the responsibility of the local governments.

\subsection{Weighting and hierarchization of indicators by experts}

The profiles of the specialists revealed that $64 \%$ of them have a master's or doctorate degree, $44 \%$ are working in the area of environmental urban planning, water resources, protected areas and related topics, and 32\% are research professors developing projects and research on the subject. At least $44 \%$ of respondents have been developing work (have been involved in urbanization work), research, or projects within the environment field (urban environmental planning, water resources, environmental protection areas, with an emphasis on urban centers) for over 6 years. In addition, some respondents had a basic education in the areas of exact sciences, for example environmental engineering (40\%), engineering (20\%), and applied social sciences (28\%), among others. This survey reflects the satisfactory academic and professional level of the experts, confirming the reliability and relevance of the responses. The specialists evaluated the indicators using the influence matrix (Table 2), wherein it is possible to observe the relationship, dependence, and influence of the indicators in the studied system.

Using MICMAC, the indicators were evaluated in pairs. The sum of total rows and columns for each indicator provides the following importance/influence ranking: $1^{\text {st }}$ EI-3 (sum 21); $2^{\text {nd }}$ EI-1 (sum 20); $3^{\text {rd }}$ UI-2 (sum 19); $4^{\text {th }}$ UI-1 (sum 15); $5^{\text {th }}$ UI-3 (sum 14); and $6^{\text {th }}$ EI-2 
(sum 13). The result selects the indicator "PPA within the municipality's environmental macrozone" as the most relevant in the system, followed by the indicator "PPA with vegetation coverage".

Table 2. Matrix of influence/importance of indicators in the studied system, according to the experts, for the water resources PPAs in Fortaleza, 2020.

\begin{tabular}{lccccccc}
\hline \multirow{2}{*}{ Indicators } & $\mathbf{1 :}$ & $\mathbf{2 :}$ & $\mathbf{3 :}$ & $\mathbf{4 :}$ & $\mathbf{5 :}$ & $\mathbf{6 :}$ & \multirow{2}{*}{ ( } \\
& UI-1 & UI-2 & UI-3 & EI-1 & EI-2 & EI-3 & Sum of lines \\
\hline 1: UI-1: sewerage coverage around PPA & 0 & 2 & 3 & 1 & 1 & 1 & $\mathbf{8}$ \\
2: UI-2: incidence of precarious settlement in PPA & 2 & 0 & 1 & 2 & 1 & 3 & $\mathbf{9}$ \\
3: UI-3: drainage system around the PPA & 3 & 2 & 0 & 1 & 1 & 1 & $\mathbf{8}$ \\
4: EI-1: PPA with vegetation coverage & 1 & 3 & 1 & 0 & 3 & 3 & $\mathbf{1 1}$ \\
5: EI-2: CU in PPA & 0 & 0 & 0 & 2 & 0 & 2 & 4 \\
6: EI-3: municipal macro-zoning in PPA & 1 & 3 & 1 & 3 & 3 & 0 & $\mathbf{1 1}$ \\
\hline Sum of columns & $\mathbf{7}$ & $\mathbf{1 0}$ & $\mathbf{6}$ & $\mathbf{9}$ & $\mathbf{9}$ & $\mathbf{1 0}$ & \\
\hline
\end{tabular}

Legend: PPA - Permanent preservation areas; UI - Urban indicators; EI - Environmental and management indicators; 0 - Not important (no influence on the system); 1 - Low importance (little influence on the system); 2 - Medium importance (medium influence on the system); 3 - Very important (strong influence on the system).

The MMP of each municipality determines the municipal environmental macro-zone, which delimits the relevant environmental fractions, indicating the use and occupation of land in these areas. The laws that institute MMPs generally consider environmental areas protected by state and federal legislation. Additionally, the municipal environmental licensing process includes the monitoring and control of these environmental macro-zones to avoid occupation and misuse of land in these areas.

\subsection{Model building: equations, standardization, and aggregates of the composite index}

Table 3 presents the results on the weighting for each indicator, obtained by multi-criteria analysis based on the Delphi method. The weights were used to compose Equations 1 through 6 for each indicator.

The urban indicator UI-1 estimates the percentage area of influence of PPAs having sewage systems (Equation 1). In theory, a sanitary sewage system reduces the possibility of undue discharge of effluents into urban water rivers, because residences connected to the sewage system do not directly dump sewage on the ground or into the river. A buffer zone (imaginary margin from the riverbed, similar to a protection zone) delimits the surrounding area based on the linear layout of the existing sewage networks, with a radius of $1 \mathrm{~m}$ on each side.

The UI-1 indicator could be improved by providing the exact number of households that are effectively connected to the sewerage system. However, in addition to the instability and continuous change in interconnected residences, information on the number of households not interconnected to the network is difficult to access. The urban indicator UI-2 partially resolves this problem by identifying the number of precarious settlements - houses with low or no access to infrastructure-located in the preservation area of urban water resources, discharging effluent into rivers, streams, lakes, and ponds.

The UI-3 indicator considers the importance of urban rivers for the drainage of large cities. It is essential that the urban drainage systems in the areas of influence of water resources be completely operational. The coverage of the urban drainage service in the areas of influence of PPAs is an indication of lower incidence of inundations and flooding in wetland areas. A buffer zone delimits this area of influence based on the linear layout of the respective drainage networks, with an adopted radius of $2 \mathrm{~m}$ for each side. 
Table 3. Code, description, weighting (AHP), and equation of each indicator according to the expert assessment for water resources PPAs in Fortaleza, 2020.

\begin{tabular}{|c|c|c|c|c|}
\hline Dimension & Code & Description of the Indicators & Weighting (AHP) & Equations \\
\hline \multirow{3}{*}{ Urban } & UI-1 & Percentage of PPA area with sewage system. & 0.26050 & Equation 1: UI1x,y $=\left(\frac{\sum \text { APPse }}{\text { PPAtotal }}\right) 100$ \\
\hline & $\mathrm{UI}-2$ & $\begin{array}{l}\text { Percentage of PPA area with no incidence of precarious } \\
\text { settlement. }\end{array}$ & 0.63335 & Equation 2: $U I 2 x, y=100-\left(\frac{\sum^{P S}}{\sum_{\text {PPAtotal }}}\right) 100$ \\
\hline & UI-3 & Percentage of PPA area served by urban drainage system. & 0.10616 & Equation 3: $U I 3 x, y=\left(\frac{\sum D S}{\sum P P A \text { total }}\right) 100$ \\
\hline \multirow{3}{*}{$\begin{array}{l}\text { Environmental and } \\
\text { managerial }\end{array}$} & EI-1 & Percentage of PPA area with plant coverage. & 0.64339 & Equation 4: $E I 1 x, y=\left(\frac{\sum P P A v c}{P P A t o t a l}\right) 100$ \\
\hline & EI-2 & Percentage of PPA area included in CUs. & 0.07377 & Equation 5: EIx, $y=\left(\frac{\sum C U p p a}{\sum P P A t o t a l}\right) 100$ \\
\hline & EI-3 & Percentage of PPA area considered in municipal macro-zoning. & 0.28284 & Equation 6: $E I x, y=\left(\frac{\sum P P A m z}{\text { PPAtotal }}\right) 100$ \\
\hline
\end{tabular}

Legend: AHP = Analytic Hierarchy Process; PPA = Permanent Preservation Area; Code $=$ indicator code $; \mathrm{x}=$ municipality; $\mathrm{y}=\mathrm{year} ; \sum$ PPA total $=$ sum of total PPA area of water resources; $\sum$ PPAse = sum of PPA area that has sewage system; $\sum$ PS = sum of PPA areas without incidence of precarious settlements; $\sum$ DS $=$ sum of PPA area with urban drainage system; $\sum$ PPAvc $=$ sum of PPA area with vegetation coverage; $\sum$ CUppa $=$ sum of conservation units inserted in PPA; $\sum$ PPAmz $=$ sum of PPA areas inserted in municipal macro-zoning.

The environmental indicator EI-1 estimates the percentage area of the PPA with native or non-native plant coverage. The management indicator EI-2 evaluates the percentage of CUs inserted in the territory of the municipality that coincide with the area of the water resources PPAs. The management indicator EI-3 estimates the percentage of PPAs protected by municipal macro-zones. In general, the municipal macro-zoning is provided for in the MMP.

After normalization, integration is carried out by applying the results of the equations (Table 3) in Equation 7, wherein the result of each indicator is multiplied by its weight and divided by the number of indicators, to obtain the arithmetic mean.

PPAWater $=\frac{(0.26 I U 1)+(0.63 I U 2)+(0.10 I U 3)+(0.64 E I 1)+(0.07 E I 2)+(0.28 E I 3)}{6}$

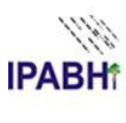

Rev. Ambient. Água vol. 16 n. 1, e2589 - Taubaté 2021 
Table 4 shows the interval scale of the PPAWater index with color distinction according to the intervals. On a scale from zero to 100 , the closer to 100 , the better the quality of the water resources PPAs. The higher the values of the indicators, according to the weights, the higher the quality of the PPAs. Next, possible scenarios are described for each level of the interval scale.

Table 4. Interval scale of the PPAWater* index.

\begin{tabular}{lc}
\hline Description of the levels & Interval \\
\hline Unconcerned management of PPAs & $0-20$ \\
Inefficient PPA management & $21-40$ \\
Regular management of PPAs & $41-60$ \\
Concerned management of PPAs & $61-80$ \\
Efficient management of PPAs & $81-100$ \\
\hline *Index of qualities of Urban Water Resource \\
Preservation Areas.
\end{tabular}

Unconcerned management of PPAs: Partial or total absence of sanitation infrastructure (sewage services, drainage system, water supply, and collection of solid waste) in the studied sub-basins or urban territory. Lack of an urban environmental management structure in the territory. Intense illegal occupation in the PPA areas.

Inefficient management of PPAs: Partial lack of sanitation infrastructure and inefficient sanitation services in the PPA areas. Existence of an agency to address the implementation of the environmental management policy in the studied territory. However, this agency does not operate satisfactorily and efficiently.

Regular management of PPAs: Existence of sanitation infrastructure with opportunities for improvement and greater coverage in the territory. Existence of an agency that deals with environmental management, with opportunities to improve its structure, governance, and implementation.

Concerned management of PPAs: Existence of sanitation infrastructure in most of the PPA areas that contribute to the dynamics of ecosystem services. Agencies responsible for environmental management policies are structured and in operation, but lack a long-term plan.

Efficient management of PPAs: Existence of sanitation infrastructure in the PPA areas. Presence of structured and planned environmental management agencies with an updated environmental information system that undertake environmental monitoring.

\subsection{Pilot study to apply the proposed PPAWater index}

The composite PPAWater index was applied to the seven typologies of the urban water resource PPAs of Fortaleza, Ceará, Brazil using 2018-2020 data. A priori, the PPAWater index was applied to the entire municipal territory of Fortaleza, presenting an overall result equal to 22.32 for PPA quality, on a scale from zero to 100 (the closer to 100, the better the quality of the water resources PPAs); the result classified the city under "inefficient management of PPAs". However, the overall result of PPA quality for the entire territory does not reveal the extremely uneven environmental quality of the city. Thus, the PPAWater index was applied to sub-river basins of the city of Fortaleza, which provided more accurate environmental quality results.

As shown in Figure 1, the sub-basins are classified by letters: "A" Vertente Marítima River Basin, "B" Cocó River Basin, "C" Maranguapinho River Basin, and "D” Pacoti River Basin. 


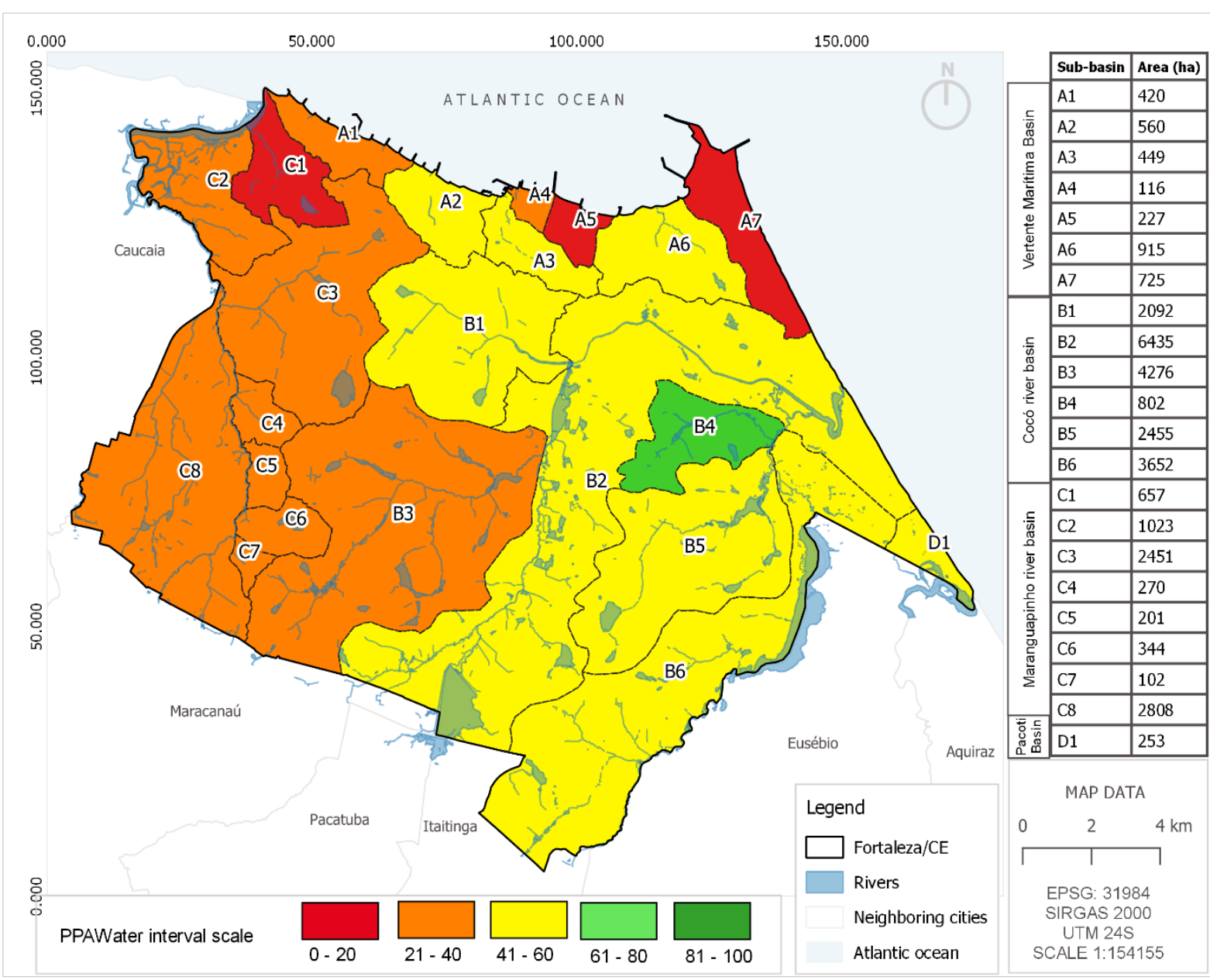

Figure 1. Application of PPAWater index to sub-river basins in Fortaleza, 2020.

Lower scores on the PPAWater scale were obtained for sub-basins with the most populated regions and poorest neighborhoods, revealing the low environmental quality of preservation areas. The sub-basins of Cocó River (B1 to B6), and other sub-basins of Vertente Marítima Basin (A2, A3, and A5), located in the upscale neighborhoods in the city, received a higher score, which can be attributed to urban infrastructure and a greater number of preservation areas. The sub-basins of the southern region of the city (B2, B4, B5, and B6) received the highest score. This region underwent urbanization more recently and the population density is lower compared to the sub-basins of the Maranguapinho River (C1, C2, C3, C4, C5, C6, C7, and C8). The areas with the highest incidence of CUs showed the highest PPA quality. These are areas of moderate urban occupation.

The results obtained for each dimension consider both the research data and field observations. In the urban dimension, according to the history of water quality monitoring in the urban lagoons and main rivers of Fortaleza, a large part of these water bodies are unsuitable for bathing because of a high level of silting. In some parts of the city, some sections of channelized rivers receive contributions from effluents of numerous residences along the banks of the canals. Sewage is released via urban drainage systems, with clandestine installations that drain effluents into rivers and lagoons; this also occurs at various points in the city.

The incidence of precarious settlements in the areas of influence of PPAs increases the vulnerability of urban water resources. The index reflects the inequality of the city, as precarious settlements occupy a total built area of $39,941,014 \mathrm{~m}^{2}$, which accounts for $32 \%$ $(246,231)$ of the residences in the city, of an estimated population of 1,077,059 (Fortaleza, 2015). In practice, the incidence of precarious settlements accompanies the design of urban 
rivers. This fact provides a strong tendency to exclude these areas in the urban context, as they are illegally occupied by individuals living on the margins of society. This situation has continued for several years, and can be interpreted as a local custom. This is a worrying finding in terms of several aspects, not only in relation to environmental issues, but also social, economic, and political concerns. The primary concerns are: people living in high-risk areas are susceptible to extreme events and the possible disposal of waste or untreated sewage in watercourses, as their houses have no sewage systems; proliferation of waterborne diseases from the consumption of polluted water; and consumption of fish from polluted waters, which can cause health problems, in addition to existing health problems.

Considering almost $40 \%$ drainage system coverage in PPAs, it is clear that the problem lies in the insufficient functioning of the systems as a result of the following factors: obstruction of drainage system by solid waste; illegal connections to the sewage system; and modifications that interfere with the flow of water. Additional problems include the fragmentation of the drainage system and its integration with intensely silted urban rivers that do not allow for satisfactory flow of water.

Regarding the environmental and management dimension, in 2019, the total area of the water resources PPAs in the municipality of Fortaleza was 3,530.28 ha. This area was estimated using geoprocessing tools (for example, software QGis), following that established in the New Brazilian Forest Code and its amendments. It was estimated that 596.47 ha $(16.9 \%)$ of the water resource PPAs in the city of Fortaleza were occupied. Within these occupied areas, 52\% were for residential use, $26 \%$ for mixed use, and $14 \%$ for commercial use.

The sum total area of the CUs in Fortaleza is 3,951 ha, with 1,920.68 ha for integral protection and 2,030.32 ha for sustainable use. Some CU areas overlap, leading to double protection. When the coincident areas are subtracted, the total area decreases to 3,693.58 ha. Most CUs in Fortaleza are near water resources, coinciding with the PPAs, that is, $42.02 \%$ $(1,483.66$ ha) of the CU areas are also water resources PPAs. The CUs, namely, Relevant Ecological Interest Area (REIA), Matinha do Pici, Cocó State Park, and Maraponga Lagoon, comprise approximately $50 \%$ of the areas included in PPAs. This coincidence can be considered as positive with regard to the protection of the water resources; however, it leads to legislative and management conflicts, as the Brazilian Forest Code offers more protective measures than certain categories of CUs. The EI-3 indicator estimates the percentage of PPA areas, established via the New Brazilian Forest Code, which are protected by municipality environmental macrozoning (established by the 2009 Master Plan and its amendments).

The calculation of the areas of Environmental Protection Zone-1 (EPZ-1; an environmental macro-zoning zone that functions to protect the water resources in the city of Fortaleza, similar to the environmental functions of the water resource PPAs), was based on the latest update of the Master Plan (Complementary Law No. 250/2018), with an estimated total of 3,530.28 ha of PPAs in the city of Fortaleza. Thus, it is estimated that $78.85 \%$ (2,783.89 ha) of the PPAs are protected by the municipality as EPZ-1. However, all areas considered in this percentage are not preserved, as some areas are occupied by pre-existing urban areas. The selected specialists evaluated this indicator as the most important, conveying the relevance of the Brazilian Forest Code in the considerations of municipal legislation. The data for occupied PPAs indicate that occupations are recurrent, particularly in areas not protected by municipal legislation. These results further confirm the importance of alignment of the MMP and the Brazilian Forest Code.

\section{CONCLUSIONS}

The following final considerations are made based on the development of this work: 
- The results offer an important scientific reference for land planning, use, and occupation, especially in the areas of water resources preservation.

- The PPAWater index is presented as an important tool in guiding urban environmental planning, public policy formulation, and management for protection of urban water resources.

- The accessibility of official data facilitates the application of the index and allows for annual monitoring. This contributes to the reliability of the data, which is essential to maintain the quality of the indicators.

- The application of the index to sub-basins leads to a better understanding of the dynamics of the built environment in relation to water resource preservation areas.

- The assessment of sub-basins in a municipal territory leads to a dialogue with municipal managers and urban planners. The results support and direct possible reformulations of urban legislation regarding the use and planning of environmentally relevant areas.

- The utilized environmental management indicators highlight the overlapping of environmental areas protected by law. This analysis directly supports the unification of environmental areas, especially the conservation units and preservation areas determined by the MMP.

- The index can help identify the areas that require prioritized attention for recovery and revitalization.

- The index colorimetric scale provides a more effective dissemination of the results and one may use it as a reference indicator in the monitoring of urban water resources PPAs.

- The index can be effectively applied on a local scale for urban agglomerations that present water resources in their territory in order to identify possible risk zones. Strategic planning is required for such zones to revitalize the preservation areas, with the participation of society and local researchers.

\section{ACKNOWLEDGEMENTS}

The authors would like to thank the Coordination for the Improvement of Higher Education Personnel (CAPES) for financing this research, through the process: 88882.343992/2019-01.

\section{REFERENCES}

AQUINO, M. D.; MOTA, S. Planejamento Ambiental e ordenamento territorial em bacias hidrográficas. In: PHILIPPI JR., A.; SOBRAL, M. DO C. Gestão de Bacias Hidrográficas e sustentabilidade. São Paulo: Manole, 2019. p. 185-204.

BAHN, G.; NA, B. Analysis of Environmental Purification Effect of Riparian Forest with Poplar Trees for Ecological Watershed Management: A Case Study in the Floodplain of the Dam Reservoir in Korea. Sustainability, v. 12, p. 1-12, 2020. http://dx.doi.org/10.3390/su12176871

BARROS, M. V. F.; MENDES, V.; CASTRO, P. H. M. Vulnerabilidade socioambiental à inundação na área urbana de Londrina/PR. Confins Revista Franco Brasileira de Geografia, v. 24, p. 1-21, 2015. https://doi.org/10.4000/confins.10228

CALDERON, M. R.; GONZÁLEZ, P.; MOGLIA, M.; GONZÁLES, S. O.; JOFRÉ, M. Use of multiple indicators to assess the environmental quality of urbanized aquatic surroundings in San Luis, Argentina. Environmental Monitoring and Assessment, v. 186, p. 44114422, 2014. https://doi.org/10.1007/s10661-014-3707-8 
CARPIO, O. V.; FATH, B. D. Assessing the Environmental Impacts of Urban Growth Using Land Use/Land Cover, Water Quality and Health Indicators: A Case Study of Arequipa, Peru. American Journal of Environmental Sciences, v. 7, n. 2, p. 90-101, 2011. https://doi.org/10.3844/ajessp.2011.90.101

CARSTENS, D.; AMER, R. Spatio-temporal analysis of urban changes and surface water $\begin{array}{lllllll}\text { quality. Journal of hydrology, } & \text { v. 569, p. } & \text { 720-734, }\end{array}$ https://doi.org/10.1016/j.jhydrol.2018.12.033

CEARÁ. Secretaria de Recursos Hídricos. Diagnóstico ambiental das bacias metropolitanas: elaboração do plano de segurança hídrica das bacias hidrográficas estratégicas do Acaraú, metropolitanas e da sub-bacia do Salgado. Fortaleza, 2018. 128 p.

COUTTS, A. M.; HARRIS, R. J.; PHAN, T.; LIVESLEY, S. J.; WILlIAMS, N. S. G.; TAPPER, N. J. Thermal infrared remote sensing of urban heat: Hotspots, vegetation, and an assessment of techniques for use in urban planning. Remote sensing of environment, v. 186, p. 637-651, 2016. https://doi.org/10.1016/j.rse.2016.09.007

DELLAMORA, F.; SILVEIRA, K.; TITOLLA, I. Indicadores de Sustentabilidade: estudo de caso de Erechim/RS. In: SEMINÁRIO NACIONAL DE CONSTRUÇÕES SUSTENTÁVEIS, 2., 7-8 Nov. 2013, Passo Fundo. Proceedings[...] Passo Fundo: SNCS, 2013. p. 1-9.

FEIL, A. A.; SCHREIBER, D. Análise da estrutura e dos critérios na elaboração de um índice de sustentabilidade. Sustentabilidade em debate, v.8, n. 2, p. 30-43, 2017. https://doi:10.18472/SustDeb.v8n2.2017.xxx

FLOSTRAND, A.; PITT, L.; BRIDSON, S. The Delphi technique in forecasting-A 42-year bibliographic analysis (1975-2017). Technological Forecasting \& Social Change, v. 150, 2020. https://doi.org/10.1016/j.techfore.2019.119773

FORTALEZA. Lei Complementar $\mathrm{n}^{\circ} 250$, de 3 de julho de 2018. Modifica a Lei Complementar $\mathrm{n}^{\circ} 62$ de 2 de fevereiro de 2009, que institui o Plano Diretor participativo de Fortaleza. Diário Oficial [do] Município, Fortaleza, 31 July 2018.

FORTALEZA. Instituto de planejamento de Fortaleza. Fortaleza 2040: Fortaleza hoje. 2015. Available at: https://fortaleza2040.fortaleza.ce.gov.br/site/assets/files/publications/fortaleza2040_imostra-virtual_11-09-2015.pdf. Access: March 2020.

FORTALEZA. Prefeitura municipal. Fortaleza em mapas. Available at: https://digital.fortaleza.ce.gov.br/planejamento-e-gestao/fortaleza-em-mapas. Access: Jan. 2020.

FREITAS, E. P.; MORAES, J. F. L.; PECHE FILHO, A.; SANTORINO, M. Indicadores ambientais para Área de Preservação Permanente. Revista Brasileira de Engenharia Agrícola e Ambiental, v. 17, n. 14, p. 443-449, 2013. http://dx.doi.org/10.1590/S141543662013000400013

FRICK, A.; TERVOONREN, S. A Framework for the Long-term Monitoring of Urban Green Volume Based on Multi-temporal and Multi-sensoral Remote Sensing Data. Journal of geovisualization and spatial analysis, v. 3, n. 6, 2019. https://doi.org/10.1007/s41651019-0030-5 
GAO, Z.; KII, M.; NONOMURA, A.; NAKAMURA, K. Urban expansion using remotesensing data and a monocentric urban model. Computers, environment and urban systems, v. 77, 2019. https://doi.org/10.1016/j.compenvurbsys.2017.05.002

GASS, S. L. B.; VERDUM, R.; CORBONNOIS, J.; LAURENT, F. Áreas de Preservação Permanente (APPs) no Brasil e na França: um comparativo. Revista Franco-Brasileira de Geografia Confins, v. 17, 2016. https://doi.org/10.4000/confins.10829

GODET, M.; DURANCE, P. A prospectiva estratégica para as empresas e os territórios. DUNOD: UNESCO, 2011. 180 p.

HEGAZY, I. R.; KALOOP, M. R. Monitoring Urban Growth and Land Use Change Detection with GIS and Remote Sensing Techniques in Daqahlia Governorate Egypt. International Journal of Sustainable Built Environment, v. 4, p. 117-124, 2015. https://doi.org/10.1016/j.ijsbe.2015.02.005

HUANG. L.; WU, J.; YAN, L. Defining and measuring urban sustainability: a review of $\begin{array}{llllll}\text { indicators. Landscape Ecology, } & \text { v. } 30, \quad \text { p. } & 1175-1193,\end{array}$ https://doi.org/10.1007/s10980-015-0208-2

IBGE. Estimativas da população dos municípios para 2019. Rio de Janeiro, 2019.

KLOPP, J. M.; PETRETTA, D. L. The urban sustainable development goal: indicators, complexity and the politics of measuring cities. Cities, v. 63, p. 92-97, 2017. https://doi.org/10.1016/j.cities.2016.12.019

LEITE, L. H.; BARROS, V. C. C.; MONTEIRO, M. E. C.; MORAES FILHO, L. O.; BORGES, L. A. C. Permanent preservation areas in Mantiqueira sierra: perspectives for regularization along watercourses. Revista Ambiente \& Água, v. 15, n. 1, 2019. https://doi:10.4136/ambi-agua.2422

LIU, X.; HE, J.; YAO, Y.; ZHANG, J.; LIANG, H.; WANG, H.; HONG, Y. Classifying urban land use by integrating remote sensing and social media data. International Journal of $\begin{array}{lllllll}\text { Geographical Information } & \text { Science, } & \text { v. } & 31, & \text { n. } & 8, & \end{array}$ http://dx.doi.org/10.1080/13658816.2017.1324976

MARINO, M. T. R. D; FREIRE, G. S. S.; HORN, N. O. F. Aspectos Geológicos e Geomorfológicos da Zona Costeira entre as Praias do Futuro e Porto das Dunas, Região Metropolitana de Fortaleza, (RMF), Ceará, Brasil. Revista de Geologia, v. 25, n. 01, p. 77-96, 2012.

MARQUES, J. B. V.; FREITAS, D. Método Delphi: caracterização e potencialização na pesquisa em Educação. Revista Pro-posições, v. 29, n. 2, p. 389-415, 2018. http://dx.doi.org/10.1590/1980-6248-2015-0140

MORENO PIRES, S. M.; FIDELIS, T.; RAMOS, T. B. Measuring and comparing local sustainable development through common indicators: Constraints and achievements in practice. Cities, v. 63, p. 92-97, 2014. https://doi.org/10.1016/j.cities.2014.02.003

OECD. Handbook on Constructing Composite Indicators: methodology and user guide, Bruxelas: European commission, 2008, 163 p.

PEDROSO JR., N. N.; STEINMETZ, S.; SANTOS, A. de C. dos; CRUZ, J. C. da C. (Coord.). Estratégia Regulatória para Áreas de Preservação Permanente Urbanas. Relatório Final Projeto de APPs urbanas. São Paulo: FGV Direito SP, 2015. 74 p. 
REISI, M.; AYE, A.; RAJABIFARD, A.; NGO, T. Transport sustainability index: Melbourne

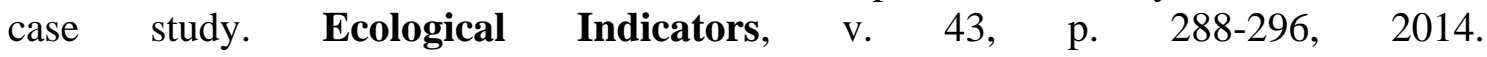
https://doi.org/10.1016/j.ecolind.2014.03.004

RIBEIRO, B. M. G.; MENDES, C. A. B. Índice de Qualidade Ambiental Urbano: uma proposta metodológica aplicada a áreas urbanas de ocupação irregular. In: SIMPÓSIO BRASILEIRO DE SENSORIAMENTO REMOTO, 17., 25-29 Apr. 2015, João Pessoa. Proceedings [...] São José dos Campos: INPE, 2015. p. 6550-6557.

SAATY, T. L. Método de Análise Hierárquica. São Paulo: Makron Books, 1991. 326 p.

SINGH, S. K.; SINGH, P.; GAUTAM, S. K. Appraisal of urban lake water quality through numerical index, multivariate statistics and earth observation data sets. International Journal of Environmental Science and Technology, v. 13, p. 445-456, 2016. http://doi.org/10.1007/s13762-015-0850-x

TU, J. Spatially varying relationships between land use and water quality across na urbanization gradient explored by geographically weighted regression. Applied Geography, v. 31, n. 1, p. 376-392, 2011. https://doi.org/10.1016/j.apgeog.2010.08.001

TU, W.; HU, Z.; LI, L.; CAO, J.; JIANG, J.; LI, Q.; LI, Q. Portraying Urban Functional Zones by Coupling Remote Sensing Imagery and Human Sensing Data. Remote sensing, v. 141, n. 10, p. 1-20, 2018. http://doi:10.3390/rs10010141

URIARTE, M.; YACKULIC, C. B.; LIM, Y.; ARCE-NAZARIO, J. A. Influence of land use on water quality in a tropical landscape: a multi-scale analysis. Landscape Ecology, v. 26, n. 8, p. 1151-1164, 2011. http://doi:10.1007/s10980-011-9642-y

XIE, W.; HUANG, Q.; HE, C.; ZHAO, X. Projecting the impacts of urban expansion on simultaneous losses of ecosystem services: A case study in Beijing, China. Ecological indicators, v. 84, p. 183-193, 2018. https://doi.org/10.1016/j.ecolind.2017.08.055

ZHAO, W.; ZHU, X.; SUN, X.; SHU, Y.; LI, Y. Water quality changes in response to urban expansion: spatially varying relations and determinants. Environmental Science and Pollution Research, v. 22, p. 16997-17001, 2015. http://doi:10.1007/s11356-015-4795-x 